\title{
Concentration- and time-dependent response of human gingival fibroblasts to fibroblast growth factor 2 immobilized on titanium dental implants
}

This article was published in the following Dove Press journal:

International Journal of Nanomedicine

13 April 2012

Number of times this article has been viewed

\section{Qianli Ma'* \\ Wei Wangl* \\ Paul K Chu \\ Shenglin Mei ${ }^{1,2}$ \\ Kun $\mathrm{Ji}^{3}$ \\ Lei Jin ${ }^{4}$ \\ Yumei Zhang' \\ 'Department of Prosthetic \\ Dentistry, School of Stomatology, \\ Fourth Military Medical University, \\ Xi'an, People's Republic of China; \\ ${ }^{2}$ Department of Physics and Materials \\ Science, City University of Hong \\ Kong, Kowloon, Hong Kong, People's \\ Republic of China; ${ }^{3}$ Department \\ of Pediatric Dentistry, School of Stomatology, Fourth Military Medical University, Xi'an, People's Republic of China; ${ }^{4}$ Stomatology Department, Jinling Hospital, School of Medicine, Southern Medical University, Nanjing, People's Republic of China \\ *These authors contributed equally to this work}

Correspondence:Yumei Zhang Department of Prosthetic Dentistry, School of Stomatology,

Fourth Military Medical University,

17 West Chang Le Road, Xi'an 7I0032,

People's Republic of China

Tel +862984776090

Fax +86 2984776096

Email wqtzym@fmmu.edu.cn

Lei Jin

Stomatology Department, Jinling Hospital, School of Medicine, Southern Medical University, 305 East Zhongshan Road,

Nanjing, 21 0002, People's

Republic of China

Tel $+86258086 I 166$

Fax +86258086II66

Email jindentist@gmail.com
Background: Titanium (Ti) implants are widely used clinically, but peri-implantitis remains one of the most common and serious complications. Healthy integration between gingival tissue and the implant surface is critical to long-term success in dental implant therapy. The objective of this study was to investigate how different concentrations of immobilized fibroblast growth factor 2 (FGF2) on the titania nanotubular surface influence the response of human gingival fibroblasts (HGFs).

Methods: Pure Ti metal was anodized at $20 \mathrm{~V}$ to form a vertically organized titanium dioxide nanotube array on which three concentrations of FGF2 $(250 \mathrm{ng} / \mathrm{mL}, 500 \mathrm{ng} / \mathrm{mL}$, or $1000 \mathrm{ng} / \mathrm{mL}$ ) were immobilized by repeated lyophilization. Surface topography was observed and FGF2 elution was detected using enzyme-linked immunosorbent assay. The bioactivity changes of dissolvable immobilized FGF2 were measured by methyl-thiazolyl-tetrazolium assay. Behavior of HGFs was evaluated using adhesion and methyl-thiazolyl-tetrazolium bromide assays.

Results: The FGF2 remained for several days on the modified surface on which HGFs were cultured. Over $90 \%$ of the dissolvable immobilized FGF2 had been eluted by Day 9, whereas the FGF2 activity was found to diminish gradually from Day 1 to Day 9 . The titania nanotubular surface with an optimal preparing concentration $(500 \mathrm{ng} / \mathrm{mL})$ of FGF2 immobilization exhibited improved HGF functions such as cellular attachment, proliferation, and extracellular matrix-related gene expression. Moreover, significant bidirectional as well as concentration- and time-dependent bioactivity was observed.

Conclusion: Synergism of the FGF2-impregnated titanium dioxide nanotubular surface revealed good gingival-implant integration, indicating that these materials might have promising applications in dentistry and other biomedical devices.

Keywords: dental implants, titanium dioxide nanotube, fibroblast growth factor 2, extracellular matrix, real-time polymerase chain reaction

\section{Introduction}

Titanium (Ti) and its alloys are widely used in dental implant therapy to treat edentulous patients but may suffer from failure due to peri-implantitis and other complications. ${ }^{1-3}$ Archival evidence supports the view that the long-term retention of an osseointegrated implant is influenced mainly by proper marginal soft tissue sealing ${ }^{4}$ of the alveolar bone below. 5,6 Furthermore, the proper dimensions and function of the soft tissue seal are prerequisite to therapeutic success. ${ }^{7,8}$ Recent studies have revealed specific differences between the microbial profiles of healthy and diseased dental implants, ${ }^{9,10}$ indicating that the loss of balance between the known periodontal pathogens and hostcompatible microbial complexes may contribute to peri-implantitis and reinfection of 
the subgingival sites. ${ }^{10} \mathrm{~A}$ well-formed soft tissue seal reduces the exposed area of the subgingival part of the implant and may reduce the formation and growth of a biofilm without disturbing the microbial balance around the implant.

Although polished Ti (PT) and Ti alloys are used in the transgingival part of conventional dental implants, they contact only the surrounding soft tissues and do not form a healthy seal at the soft tissue-implant interface by themselves. Manipulating the structure of Ti is a possible way to enhance soft tissue compatibility on Ti dental implants. The shape, surface topography, design, physicochemical properties, and even the method used to sterilize the Ti implant may affect the integration between the implant and soft tissues. ${ }^{11,12}$ The method is quite promising for tissue regeneration, due to the well-organized and porous Ti nanostructure that forms the biocompatible surface.

A titanium dioxide $\left(\mathrm{TiO}_{2}\right)$ nanotubular structure can be formed on $\mathrm{Ti}$ by anodization of a relatively large surface area to enable bioactive factor absorption. ${ }^{13,14}$ According to previous studies, the $\mathrm{TiO}_{2}$ nanotubular structure can affect functions such as adhesion, orientation, proliferation, and gene expression in various types of cells. ${ }^{14-17}$ In addition, the $\mathrm{TiO}_{2}$ nanotubular surface with a tube size of $\sim 120 \mathrm{~nm}$ exhibits better electrochemical stability in artificial saliva as well as improved adhesion and proliferation of human gingival fibroblasts (HGFs). ${ }^{18}$

Fibroblast growth factors (FGFs) are a large family of polypeptide growth factors that regulate the secretion of various extracellular matrix (ECM) proteins, which contribute to the formation of new blood vessels. ${ }^{19,20}$ Fibroblast growth factor 2 (FGF2) is a potent mitogen in a variety of cells and is effective in regulating the proliferation and ECM-related gene expression of fibroblasts, ${ }^{21,22}$ the most common cell type in peri-implant gingival connective tissue.

To control the responses of cells and tissues toward biomaterials, modification of surfaces and immobilization of biomolecules have been widely studied. ${ }^{23}$ FGF2 can be immobilized on Ti surfaces pretreated with oxygen plasma, ${ }^{24}$ and the $\mathrm{TiO}_{2}$ nanotubular surface benefits drug control release $\mathrm{e}^{25}$ and immobilization of other growth factors such as, bone morphogenetic protein 2 as well. ${ }^{14}$ Hence, a $\mathrm{TiO}_{2}$ nanotubular surface and FGF2 may be used together to improve early gingival tissue-implant integration by enhancing the functions of surrounding HGFs. However, according to previous studies, the effects of FGF2 may depend on the concentration of FGF2 in the culture medium, suggesting that improper amounts of FGF2 on the Ti surface may spur adverse effects. ${ }^{26}$ Although the behavior of some cells on surfaces with different topographies has been investigated, the relationship between the behavior of HGFs around dental implants and variable FGF2 immobilization has not been systematically studied. ${ }^{27-29}$ Hence, a better understanding of this issue will help to mimic natural gingival tissue-implant integration.

In the work reported here, Ti samples were anodized at $20 \mathrm{~V}$ to form a vertically organized $\mathrm{TiO}_{2}$ nanotubular surface, and FGF2 solutions of three different concentrations were used to immobilize FGF2 on the nanotubular surface by repeated lyophilization. The objectives of this study are to investigate how different concentrations of immobilized FGF2 on the titania nanotubular surface influence the response of HGFs, and to determine the associated mechanism.

\section{Materials and methods \\ Sample preparation}

Pure Ti foils $\left(99.9 \%, 1000 \times 500 \times 0.6 \mathrm{~mm}^{3}\right.$, supplied by Northwest Institute for Nonferrous Metal Research, Xi'an, People's Republic of China) were cut into $10 \times 10 \times 0.6 \mathrm{~mm}^{3}$ pieces, polished with 400 - to 1500 -grit silicon carbide sandpaper in running water, and ultrasonically cleaned in acetone, $70 \%$ ethanol, and doubly distilled water for 10 minutes sequentially. They were then dried at $50^{\circ} \mathrm{C}$ for 20 minutes under flowing nitrogen. The PT samples were anodized in an electrolyte solution containing $0.5 \%$ ammonium fluoride and $1 \mathrm{M}$ ammonium sulfate at $20 \mathrm{~V}$ for 45 minutes $^{18}$ using a Ti anode and a PT cathode. During anodization, the electrolyte was stirred constantly, and afterwards the samples were ultrasonically cleaned and dried as described previously to obtain the nanotube (NT) samples.

\section{Immobilization of FGF2}

The NT samples were sterilized by ultraviolet A (peak wavelength $365 \mathrm{~nm}$, Philips TL-D $18 \mathrm{WBL}$, the Netherlands) and C (peak wavelength $253.7 \mathrm{~nm}$, Philips TUV 15W, Poland) irradiation at a distance of $30 \mathrm{~mm}$ for 2 hours each, because ultraviolet sterilization inactivates bacteria without organic contamination and decomposes existing organic species on the titania surface by photocatalysis. ${ }^{30}$ The Escherichia coli source recombinant human FGF2 (Peprotech, UK) was reconstituted in Tris-HCl buffered solution ( $\mathrm{pH}$ 7.6, Sigma-Aldrich, St, Louis, MO) with $0.1 \%$ bovine serum album (Gibco, US). The FGF2 was diluted to $250 \mathrm{ng} / \mathrm{mL}, 500 \mathrm{ng} / \mathrm{mL}$, or $1000 \mathrm{ng} / \mathrm{mL}$. The NT samples were divided into three groups designated as 
NT-F-L, NT-F-M, and NT-F-H, corresponding respectively to the FGF2 concentrations. Each group was incubated in the appropriate FGF2 solution for 10 minutes at $4^{\circ} \mathrm{C}$ in an orbital shaker (45 rpm, MaxQ 8000, Thermo, US) and then lyophilized (Alpha 1-4 LSC, Chirst, Germany) at $-50^{\circ} \mathrm{C}$ overnight to obtain three types of FGF2-immobilized samples. The immobilization procedures were repeated thrice.

\section{Surface analysis}

The FGF2 on the NT-F-L/M/H samples was examined by an immunofluorescence assay. ${ }^{24}$ After FGF2 immobilization, the samples were gently washed thrice with phosphate buffered saline (PBS, $\mathrm{pH}=7.4$ ) for 5 minutes, treated with rabbit anti-bFGF polyclonal antibody (1:200; Sigma-Aldrich) as the primary antibody at $4{ }^{\circ} \mathrm{C}$ overnight, and washed thrice with PBS. The samples were then treated with fluorescein isothiocyanate-labeled goat antirabbit immunoglobulin $\mathrm{G}$ (1:200; Bois, People's Republic of China) for 1 hour at $37^{\circ} \mathrm{C}$ and washed thrice in PBS $(\mathrm{pH}=7.4)$. The samples were inspected by laser confocal microscopy (Olympus FV-1000, Japan). In order to evaluate the remaining FGF2 on the nanotubular surface over a specific time interval, a portion of the FGF2 immobilized samples was incubated in PBS at $37^{\circ} \mathrm{C}$ for 9 days (with a change in PBS every 3 days), and then the immunofluorescence procedures were repeated as described previously.

To measure the elution of FGF2 versus time, samples were immersed in PBS ( $1 \mathrm{~mL}$ per sample) at $4^{\circ} \mathrm{C}$ (to preserve the activity of FGF2) for 1 day, 2 days, 3 days, 4 days, 6 days, 9 days, 15 days, 21 days, or 30 days. Utilizing the standard curve of FGF2, the FGF2 concentrations in the extracts were determined by the enzyme-linked immunosorbent assay (Quantikine ${ }^{\circledR}$ Human FGF Basic Immunoassay, R\&D, US), and the amounts of dissolved FGF were also calculated.

\section{Surface characterization}

Surface and material characterization was conducted on five types of samples. Field emission scanning electron microscopy (FE-SEM; JSM-6460, JEOL, Japan) and atomic force microscopy (AFM; SPM400, SEIKO, Japan) were employed to observe and measure (Adobe Photoshop CS2) the surface microstructure as well as surface roughness.

\section{Behavior of HGFs}

The HGFs were obtained from three periodontally healthy patients (aged 19 years, 33 years, and 46 years) undergoing crown-lengthening surgery. Ethical approval and consent was obtained from all three volunteers. The gingival tissues were washed in PBS containing 100,000 U penicillin/gentamicin twice and incubated in $1 \mathrm{U} / \mathrm{mL}$ Dispase ${ }^{\circledR}$ II solution (Roche, US) overnight to separate the connective tissues from the epithelium. The tissues were then sheared into $1.0 \mathrm{~mm}^{3}$ cubes cultured in Dulbecco's modified Eagle's medium (DMEM, Gibco) with 10\% fetal calf serum (FCS, Gibco) and 100,000 $\mathrm{U}$ penicillin/gentamicin (Roche) and incubated in a humidified atmosphere of $5 \% \mathrm{CO}_{2}$ at $37^{\circ} \mathrm{C}$.

HGFs at passage 4 were used for further analysis. The $1 \mathrm{~mL}$ HGF suspension was seeded on each sample (serumfree $)$ at the density $1 \times 10^{5}$ cells $/ \mathrm{mL}\left(\sim 5 \times 10^{4}\right.$ cells $\left./ \mathrm{cm}^{2}\right)$ and cultured for 30 minutes, 60 minutes, or 120 minutes to allow attachment. At each time interval, the samples were washed with PBS to remove nonattaching cells. Afterwards, the attached cells were fixed in $4 \%$ formalin and stained with $4^{\prime}, 6^{\prime}$-diamidino-2-phenylindole (DAPI; $1 \mu \mathrm{g} / \mathrm{mL}$; Roche). ${ }^{12}$ The images were captured from the four corners and the center of each sample $(2.60 \mathrm{~mm} \times 1.94 \mathrm{~mm}$, five fields per sample) using a fluorescence microscope (Leica DMI6000B, Germany). Three of five images were randomly selected (by random number table). Image $J$ software (National Institutes of Health) was employed to convert the original images to binary images, and black particles were counted to obtain the number of attached cells. The results were calculated as relative cell attachment rates (RCARs) to balance the height of data bars among groups as follows:

$\mathrm{RCAR}, \%=\left(\mathrm{COUNT}_{\mathrm{T}} / \mathrm{COUNT}_{\mathrm{P}}\right) \times 100 \%$, where $\mathrm{COUNT}_{\mathrm{T}}$ represents the mean value of the cell number counted on the tested samples and $\mathrm{COUNT}_{\mathrm{P}}$ is the mean value of the cell number on the PT control.

Cell proliferation was evaluated by the methyl-thiazolyltetrazolium (MTT) bromide assay. Briefly, five groups of samples (three samples per group) were placed in a 24-well dish (Costar 3524, US) and $4 \times 10^{4}$ HGF cells were seeded in each well and cultured in DMEM with $10 \%$ bovine calf serum. On Day 1, Day 3, Day 6, and Day 9, the samples were gently washed three times with PBS and placed on a new 24-well dish. The MTT-PBS (Amresco, US) solutions ( $5 \mathrm{mg} / \mathrm{mL}$ ) were prepared and filter sterilized. The MTT solution $(200 \mu \mathrm{L})$ and serum-free/phenol red-free DMEM $(800 \mu \mathrm{L})$ were added to each well and the samples were incubated at $37^{\circ} \mathrm{C}$ for 4 hours to form formazen. Afterwards, formazen was dissolved in dimethyl sulfoxide (DMSO; $1 \mathrm{~mL} /$ well). Two hundred microliters of the mixed solution was transferred to a new 96-well dish and the optical density value of each well was monitored at $490 \mathrm{~nm}$ using a spectrophotometer (Bio-tek, US). ${ }^{12,18}$ 


\section{Morphological observation of HGFs}

A $1 \mathrm{~mL}$ cell suspension at a density of $2 \times 10^{4}$ cells $/ \mathrm{mL}$ was seeded on each sample and cultured in DMEM with $10 \%$ bovine calf serum. After 3 days, the samples were fixed in a $2.5 \%$ glutaraldehyde solution. After a series of dehydration (in graded acetone and isoamyl acetate) and desiccation (lyophilization), the samples were gold-coated and the cell morphology was observed by FE-SEM (JSM6460, JEOL).

\section{ECM-related gene expression}

Expressions of the ECM-related genes were analyzed using quantitative real-time polymerase chain reaction (RT-PCR). The HGFs were cultured in the same manner as described in the proliferation assay. The total RNA of each sample was extracted with TRIzol reagent (Invitrogen). One microgram total of RNA from each sample was reverse transcribed into complementary DNA (cDNA, $50 \mu \mathrm{L}$ system) using the PrimeScript ${ }^{\mathrm{TM}} \mathrm{RT}$ reagent kit (TaKaRa, Japan). Quantitative PCR was conducted on the ABI7500 RT-PCR system to determine the mRNA relative expression of the ECMrelated genes including vascular endothelial growth factor $\mathrm{A}$ (VEGFA), $\beta$-integrin (ITGB), intercellular adhesion molecule 1 (ICAM1), and laminin-1 (LAMA1) using SYBR ${ }^{\circledR}$ Premix $\mathrm{Ex}^{\mathrm{TM}}$ TaqII (TaKaRa). The forward/reverse primers for the selected genes are listed in Table 1. The PCR efficiency was compared. The relative expression levels for each gene of interest were normalized to the expression of the housekeeping gene glyceraldehyde 3-phosphate dehydrogenase $(G A P D H)$ by calculating the change $(\Delta)$ in cycle threshold $(\mathrm{Ct}): \Delta \mathrm{Ct}=\left(\mathrm{Ct}_{\text {gene of interest }}-\mathrm{Ct}_{\text {GAPDH }}\right)$, and the expression of the different genes was expressed as $2^{-(\Delta \mathrm{Ct})}$. The gene expression of PT as the control was normalized to $1 .{ }^{31}$ The specificity of every pair of PCR primers was confirmed by analyzing the melting curves, and the data were analyzed using the Applied Biosystem Software in the Excel ${ }^{\circledR}$ format.

\section{Bioactivity changes of immobilized FGF2}

To evaluate the bioactivity changes of FGF2 after repeated lyophilization, $1000 \mathrm{ng}$ of FGF2 was pretreated with three cycles of lyophilization dissolution and diluted to $10 \mathrm{ng} / \mathrm{mL}$ in $100 \mathrm{~mL}$ of DMEM (serum-free). The FGF2-loaded DMEM was divided into five groups and stored at $37^{\circ} \mathrm{C}$ to be used at five different time intervals: newly prepared (NP) and S1, S3, S6, S9 (stored for 1 day, 3 days, 6 days, and 9 days, respectively). The PT samples were placed in 24-well dishes (three samples per group), and $4 \times 10^{4} \mathrm{HGF}$ cells were seeded on each well. The samples were cultured in
Table I Target cDNA primer sequences used in quantitative polymerase chain reaction

VEGFA

Forward: 5'-GAGCCTTGCCTTGCTGCTCTAC-3'

Reverse: 5'-CACCAGGGTCTCGATTGGATG-3'

PCR product size: 148 bp

ITGB

Forward: 5'-TGTGTCAGACCTGCCTTGGTG-3'

Reverse: 5'-AGGAACATTCCTGTGTGCATGTG-3'

PCR product size: $105 \mathrm{bp}$

ICAMI

Forward: TGAGCAATGTGCAAGAAGATAGC

Reverse: CCCGTTCTGGAGTCCAGTACA

PCR product size: $105 \mathrm{bp}$

LAMAI

Forward: TGGTAACATTTGCCACCACGA

Reverse: TTGCCTCCGATCAGCATGAC

PCR product size: 127 bp

GAPDH (housekeeping gene)

Forward: 5'-GCACCGTCAAGGCTGAGAAC-3'

Reverse: 5'-TGGTGAAGACGCCAGTGGA-3'

PCR product size: 138 bp

Abbreviations: GAPDH, glyceraldehyde 3-phosphate dehydrogenase; ICAMI, intercellular adhesion molecule I; ITGB, $\beta$-integrin; LAMAI, laminin-I; VEGFA, vascular endothelial growth factor $\mathrm{A}$.

FGF2-free DMEM or one of the five types of FGF2-loaded DMEM. After 24 hours, the samples were placed in a new 24-well dish, and the proliferation activity was monitored using the MTT assay as described previously.

\section{Statistical analyses}

The data were analyzed using SPSS 18.0 software (SPSS, Inc, Chicago, IL). The statistical results were presented as means \pm standard deviation and analyzed by one-way analysis of variance followed by a Student-Newman-Keuls post hoc test to identify significant differences among the groups (multiple comparisons). ${ }^{12}$ When the probability value $(P)$ was less than 0.01 , the difference was regarded as significant.

\section{Results}

\section{Surface characterization}

The FGF2-immobilized surfaces (NT-F-L/M/H) generated fluorescence both initially and after 9 days, but no fluorescence was observed from the PT or NTs (Figure 1). FGF2 was found to be immobilized on the $\mathrm{TiO}_{2}$ nanotubular surface and remained so for a certain period of time. The surface morphology of the samples is displayed in Figure 2 (FESEM) and Figure 3 (AFM). On the nanoscale, the $\mathrm{TiO}_{2} \mathrm{NTs}$ are organized in a vertical array with a diameter of $\sim 100 \mathrm{~nm}$ (Figure 2A) and tube length $588.8 \pm 31.92 \mathrm{~nm}$ (Figure 2B). On the FGF2-immobilized nanotubular surfaces, FGF2 


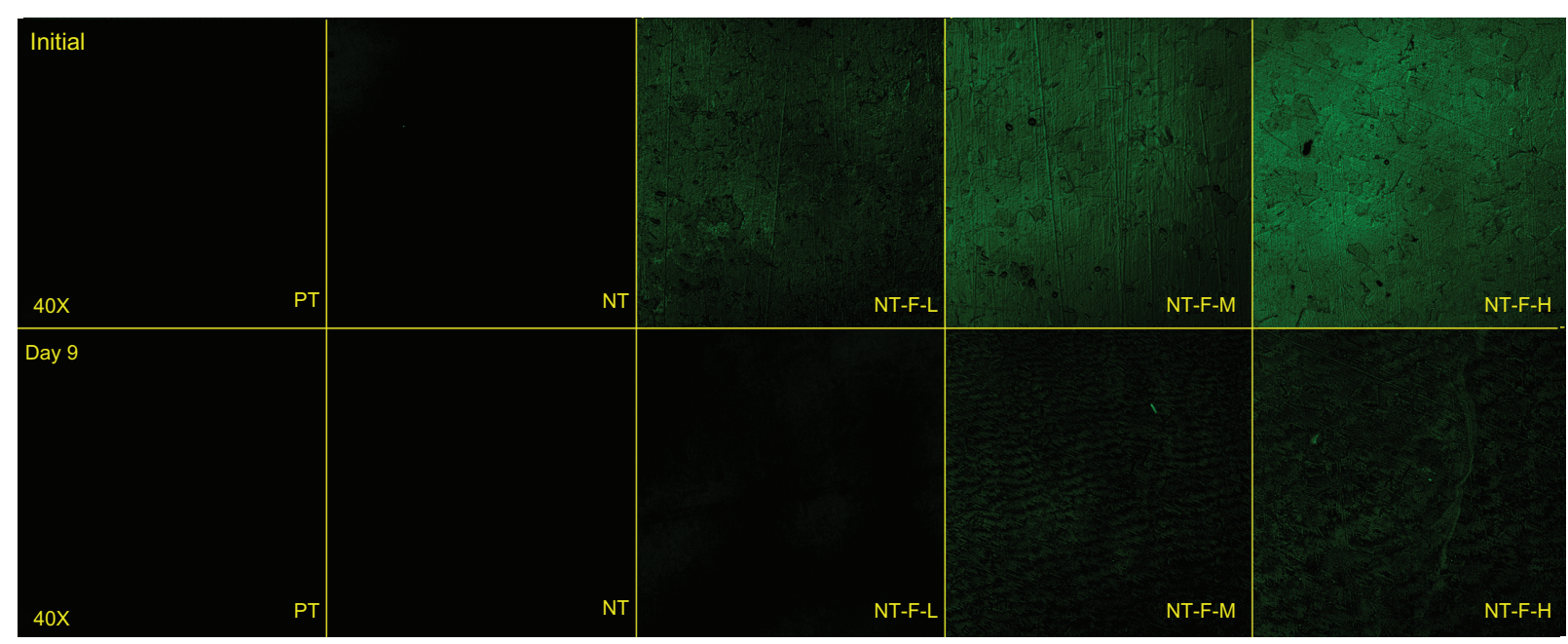

Figure I Immobilized FGF2 compared with FGF2-free samples initially and after 9 days. Abbreviations: FGF2, fibroblast growth factor 2; NT, nanotube; PT, polished titanium.
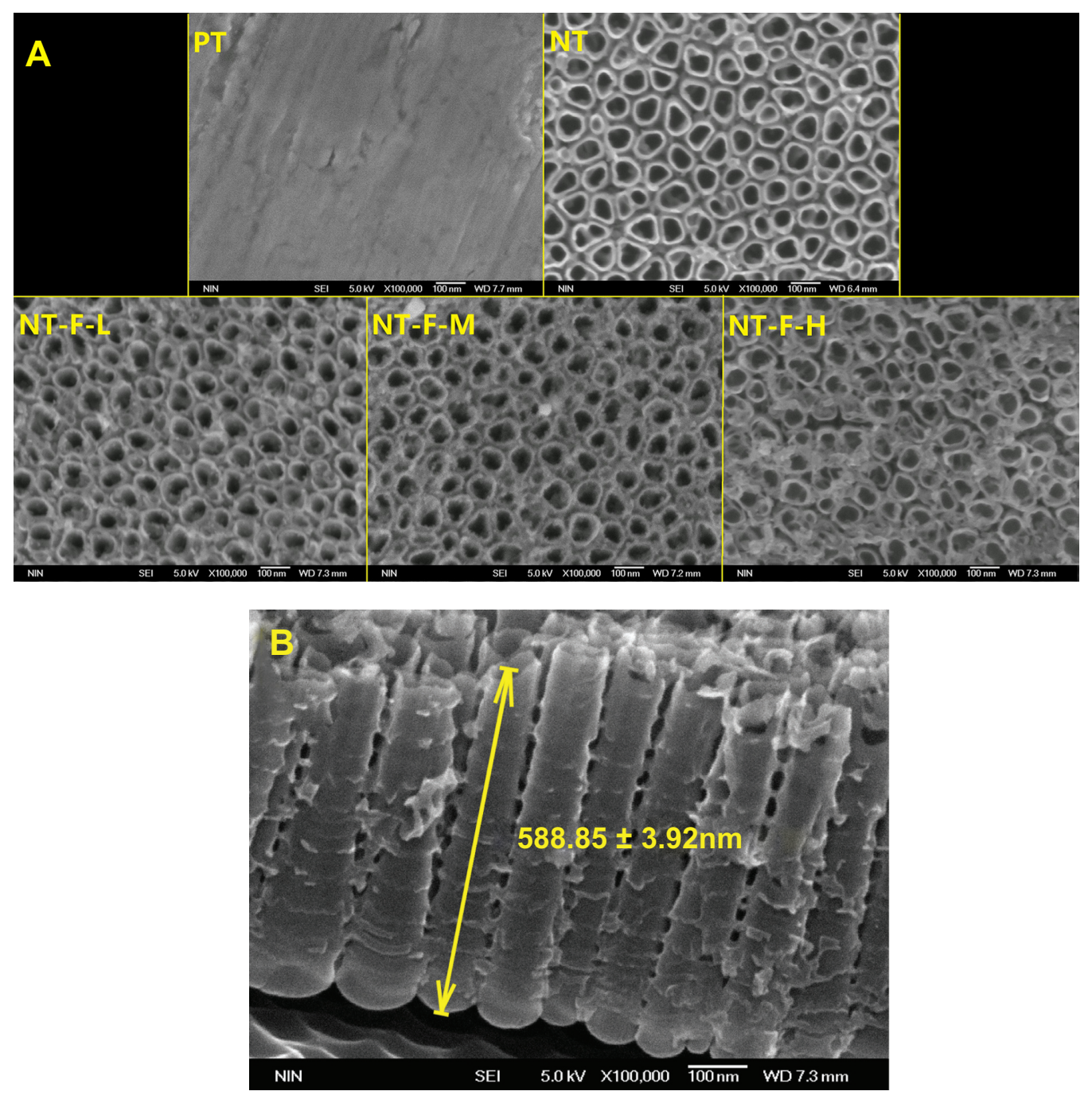

Figure 2 Field emission scanning electron microscopy results. (A) NT surface showed an NT array structure; NT-F-H surface showed clumps of fibroblast growth factor 2 and that the typical NT surface was changed. (B) Profile of titania NT.

Note: The length of NT was $588.85 \pm 31.92 \mathrm{~nm}$ (mean value \pm standard deviation)

Abbreviations: NT, nanotube; PT, polished titanium. 


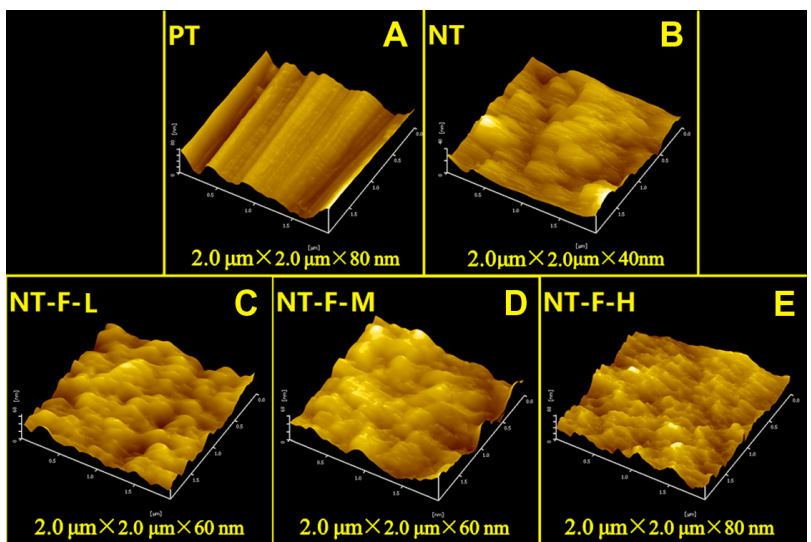

Figure 3 Atomic force microscopy images of different surfaces: (A) PT, (B) NT, (C) NT-F-L, (D) NT-F-M, and (E) NT-F-H. PT showed a microgroove structure, and porous-like structures were observed in other groups. Abbreviations: NT, nanotube; PT, polished titanium.

adsorbs on to the $\mathrm{TiO}_{2}$ NT walls homogeneously on NT-F-L and NT-F-M. The morphology is evidently different from that of NT-F-H. The FGF2 on NT-F-H manifested as clumps or cord-like aggregates with a nonuniform distribution. On the microscale, PT demonstrated a microgroove-like surface structure that was a lot rougher than the other four types of NT-based surfaces that have similar nanoporous structures. Anodization produced a smooth Ti surface, whereas the surface roughness barely changed after FGF2 immobilization (Figure 3 and Table 2).

\section{Elution kinetics of immobilized FGF2}

Results of the elution kinetics are shown in Figure 4 and Table 3. The immobilized FGF2 was released from all the samples rapidly within the first 3 days, followed by a gradual reduction in the elution rate. On Day 9, over $90 \%$ of the dissolvable immobilized FGF2 had been eluted (with the total amount of dissolvable FGF2 in 30 days considered

Table 2 Measurement of surface roughness by atomic force microscopy

\begin{tabular}{llc}
\hline Group & $\mathbf{R}_{\mathbf{a}}$ & \multicolumn{1}{l}{ RMS } \\
\hline PT & $32.60 \pm 3.45 \mathrm{~nm}$ & $41.70 \pm 3.96 \mathrm{~nm}$ \\
NT & $4.96 \pm 0.50 \mathrm{~nm}^{*}$ & $6.23 \pm 0.80 \mathrm{~nm}^{*}$ \\
NT-F-L & $7.25 \pm 0.97 \mathrm{~nm}^{*}$ & $9.14 \pm 1.25 \mathrm{~nm}^{*}$ \\
NT-F-M & $9.70 \pm 1.85 \mathrm{~nm}^{*}$ & $11.80 \pm 2.21 \mathrm{~nm}^{*}$ \\
NT-F-H & $9.42 \pm 1.99 \mathrm{~nm}^{*}$ & $11.79 \pm 2.35 \mathrm{~nm}^{*}$ \\
\hline
\end{tabular}

Notes: * Lower $\mathrm{R}_{\mathrm{a}}$ and RMS compared with PT $(P<0.0 \mathrm{I})$. Anodization significantly smoothed titanium surface, whereas surface roughness was barely affected by FGF2 immobilization.

Abbreviations: FGF2, fibroblast growth factor 2; NT, nanotube; PT, polished titanium; $R_{a}$, average roughness, RMS, root mean square roughness.

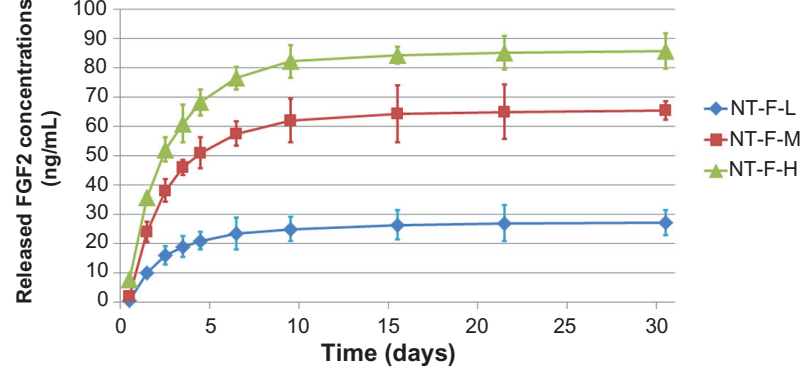

Figure 4 Elution kinetics of various FGF2 immobilizations. FGF2 eluted rapidly within first 3 days and the elution velocity reduced with time. Approximately all dissolvable FGF2 eluted within 30 days.

Abbreviations: FGF2, fibroblast growth factor 2; NT, nanotube.

$100 \%$ likely elution). Almost all the dissolvable FGF2 was eluted in 21 days, after which (up to 30 days) the amount of additional elution was negligible.

\section{Behavior of HGFs}

The HGF adhesion assay results are displayed in Figure 5A, and the RCAR results are shown in Figure 5B. The number of adhered cells on the NT-F-L and -M are significantly larger than those on the PT, NT, or NT-F-H at 30 minutes, 60 minutes, and 120 minutes $(P<0.01)$. NT-F-M shows the highest cell adhesion among the tested samples. Cell adhesion on NT and NT-F-H samples is significantly suppressed $(<50 \%)$ compared with PT. The $\mathrm{TiO}_{2}$ NT array without FGF2 or with over FGF2 immobilization appears to impair HGF adhesion.

The results of the cell proliferation study are depicted in Figure 6. Compared with PT, NT-F-L and NT-F-M have enhanced HGF proliferation at all time points, whereas NT shows enhanced proliferation on Day 3 only $(P<0.01)$. NT-F-H exhibited extremely low cell proliferation on Days 1 and 3, but improved HGF proliferation was noted on Days 6 and 9. Nevertheless, the enhanced effect of NT-F-H was not as substantial as that observed from NT-F-L and NT-F-M. The morphology of HGFs on the samples is displayed in Figure 7. The observed morphological differences of HGFs among the PT, NT, NT-F-L, and NTF-M samples are slight. The HGFs on the NT-F-H surface were narrow, with fewer prominences or pseudopods under normal conditions. Furthermore, HGFs on the NT-F-H surface did not fuse together or demonstrate any trend to form tissue-like structures during the time.

Adequate ECM-related gene expression is expected to realize wound healing and tissue regeneration. The results of ECM-related gene expression on different surfaces are shown in Figure 8. The HGFs on NT-F-L and NT-F-M show 
Table 3 Elution of dissolvable FGF2 at different time intervals*

\begin{tabular}{|c|c|c|c|c|c|c|}
\hline \multirow[t]{2}{*}{ Time interval } & \multicolumn{2}{|c|}{ NT-F-L } & \multicolumn{2}{|c|}{ NT-F-M } & \multicolumn{2}{|c|}{ NT-F-H } \\
\hline & $\begin{array}{l}\text { Mass } \\
\text { (ng) }\end{array}$ & $\begin{array}{l}\text { Percent } \\
\text { (accumulative) }\end{array}$ & $\begin{array}{l}\text { Mass } \\
\text { (ng) }\end{array}$ & $\begin{array}{l}\text { Percent } \\
\text { (accumulative) }\end{array}$ & $\begin{array}{l}\text { Mass } \\
\text { (ng) }\end{array}$ & $\begin{array}{l}\text { Percent } \\
\text { (accumulative) }\end{array}$ \\
\hline D0 DI & 10 & 36.76 & 24 & 36.70 & 35.6 & 41.59 \\
\hline DI D2 & 6 & 58.82 & 14.1 & 58.26 & 16.5 & 60.86 \\
\hline D2 D3 & 3 & 69.85 & 7.9 & 70.34 & 8.9 & 71.26 \\
\hline D3 D6 & 4.5 & 86.40 & 11.5 & 87.92 & 15.5 & 89.37 \\
\hline D6 D9 & 1.5 & 91.91 & 4.5 & 94.80 & 5.7 & 96.03 \\
\hline D9 DI5 & 1.4 & 97.06 & 2.3 & 98.32 & 2.1 & 98.48 \\
\hline DI5 D2I & 0.6 & 99.26 & 0.7 & 99.39 & 0.8 & 99.42 \\
\hline D2I D30 & 0.2 & 100.00 & 0.4 & 100.00 & 0.5 & 100.00 \\
\hline
\end{tabular}

Notes: *Average amounts and accumulative percent of eluted FGF2 at each time interval. FGF2 rapidly eluted within the first 3 days, followed by a gradual reduction in elution. Over $90 \%$ of the dissolvable immobilized FGF2 eluted within 9 days. After 21 days, additional elution was negligible.

Abbreviations: FGF2, fibroblast growth factor 2; NT, nanotube; PT, polished titanium.

beneficial ECM-related gene expression, and the details of the ECM-related gene expressions are summarized in Table 4.

\section{Bioactivity changes of immobilized FGF2}

The changes in bioactivity of immobilized FGF 2 are shown in

Figure 9. The activity of FGF2 was not significantly affected by repeated lyophilization-dissolving cycles but reduced gradually over time $(\mathrm{NP} \approx \mathrm{S} 1>\mathrm{S} 3 \approx \mathrm{S} 6>\mathrm{S} 9)$ at $37^{\circ} \mathrm{C}$. After storing for 9 days (S9), the activity of FGF2 was reduced to less than 50\% compared with NP. Proteolytic degradation may be the main reason for the loss of activity due to the absence of the protective ECM component ${ }^{32}$ in DMEM.

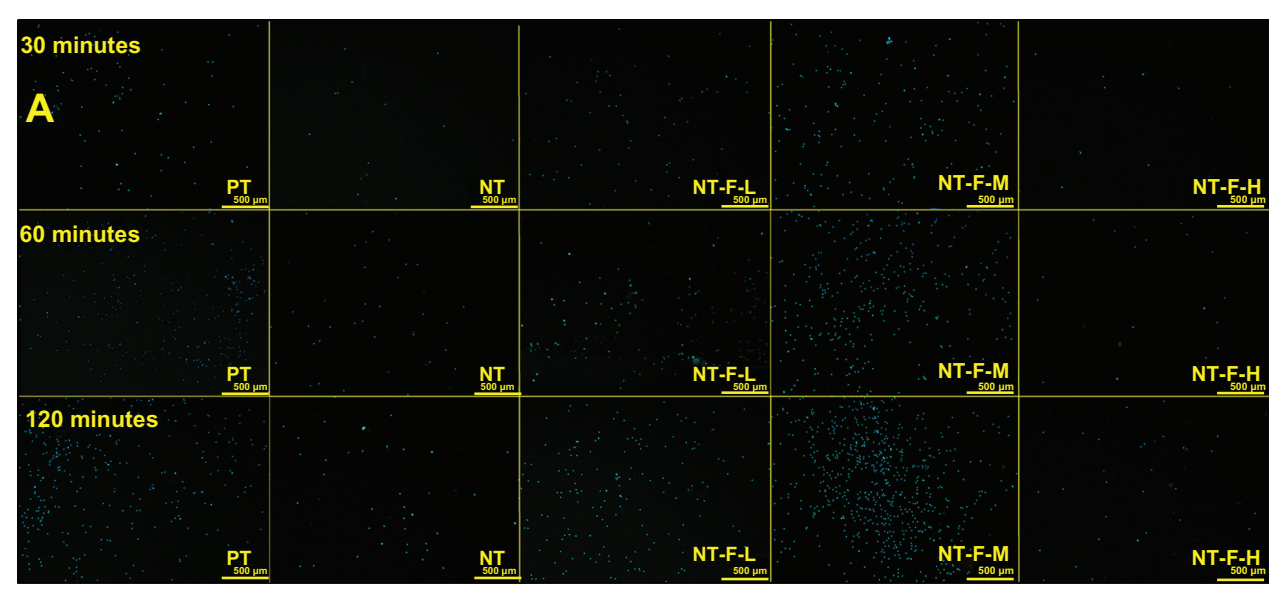

B Relative cell attachment rates

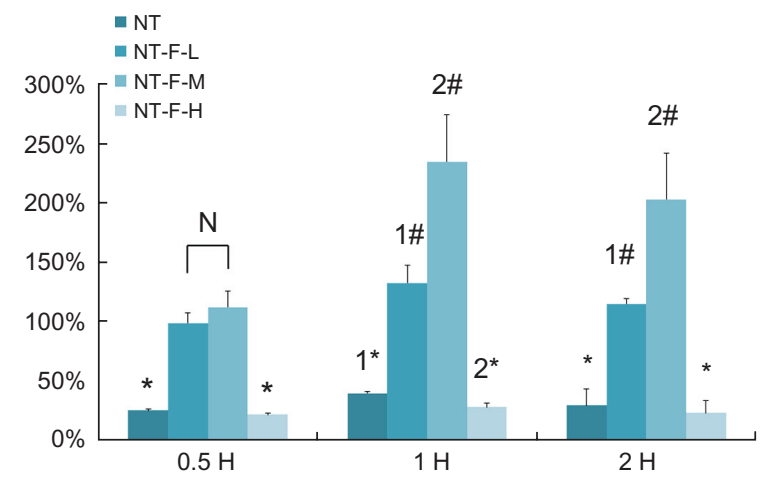

Figure 5 HGF adhesion. (A) HGFs attached to the substrates with 4',6'-diamidino-2-phenylindole stain and (B) relative cell adhesion rate of attached HGFs. The NT and NT-F-H surfaces inhibited cell adhesion, whereas the NT-F-L and NT-F-M improved cell attachment.

Notes: "Higher than PT $(P<0.0 \mathrm{I})$, *lower than PT $(P<0.0 \mathrm{I})$, difference also exists between I*, $2^{*}, \mathrm{I}^{\#}$, and $2^{*}(P<0.0 \mathrm{I})$.

Abbreviations: HGF, human gingival fibroblast; NT, nanotube; PT, polished titanium. 


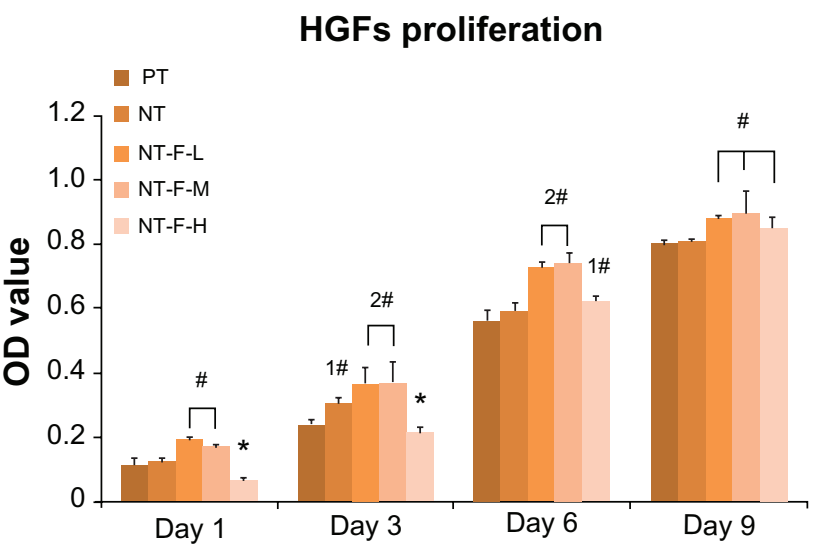

Figure 6 Cell proliferation measured by the methyl-thiazolyl-tetrazolium assay. NT-F-L and NT-F-M showed the higher cell proliferation at each interval, whereas NT-F-H with overimmobilized FGF2 showed the lowest at the early stage (Days I and 3).

Notes: "Higher than PT $(P<0.0 \mathrm{I})$, *lower than PT $(P<0.0 \mathrm{I})$, significant difference exists between $\mathrm{I}^{\#}$ and $2^{\#}(P<0.0 \mathrm{I})$.

Abbreviations: FGF2, fibroblast growth factor 2; NT, nanotube; OD, optical density; PT, polished titanium.

\section{Discussion and conclusion}

Unlike previous methods used to prepare microscale porous $\mathrm{TiO}_{2}$ films, ${ }^{33,34}$ in the present study, $\mathrm{F}^{+}$-based electrolyte anodization was used to obtain the $\mathrm{TiO}_{2}$ nanotubular surface on dental implants. However, in the transgingival part of a Ti dental implant, a smooth surface helps to maintain cleanliness. It has been shown that various types of cells have dissimilar reactions to different nanotubular surfaces of disparate tube sizes. ${ }^{14-16,18,35}$ Sterilization also affects the cytocompatibility of the $\mathrm{TiO}_{2}$ surface, and ultraviolet irradiation is one of the methods to improve the bioactivity of $\mathrm{TiO}_{2}$ without unexpected biological contamination. ${ }^{35}$

Application of FGF2 to periodontal tissue regeneration has been previously reported. ${ }^{36,37}$ FGF2 can be immobilized on to Ti surface ${ }^{24}$ and hydroxyapatite-chitosan scaffolds. ${ }^{38}$ The immobilization procedure used in this study as well as the chemical inertness and stability of $\mathrm{TiO}_{2}$ ensure that there is very little possibility for the FGF2 to react with the $\mathrm{TiO}_{2}$ NT array. Besides, using a $\mathrm{TiO}_{2}$ nanotubular surface for long-term drug elution is feasible due to its multitubular-like structure and ability to trap relatively small amounts of drug. ${ }^{25}$ FGF2 $(17 \mathrm{kDa})$ is approximately $1.45 \mathrm{~nm}^{39}$ in hydrodynamic radius, and a biomolecule with such a small size is more likely to enter the inner space of the $\mathrm{TiO}_{2} \mathrm{NTs}$ (Figure 10). Intratube FGF2 storage may provide the possibility for an NT-based control release system. Although the total amount of immobilized FGF2 is difficult to quantify accurately, the elution kinetics of dissolvable immobilized FGF2 can be monitored with an enzyme-linked immunosorbent assay. The elution curves in this study are similar to those reported previously by Peng et $\mathrm{al}^{25}{ }^{25}$ indicating that the length of the NT mainly affects the controlled release of immobilized FGF2.

Compared with PT, NT and NT-F-H exhibit significantly suppressed cell adhesion probably because of the surface physicochemical properties and nanotopography. The $\mathrm{TiO}_{2}$ NT array has a multiringed shape with small initial

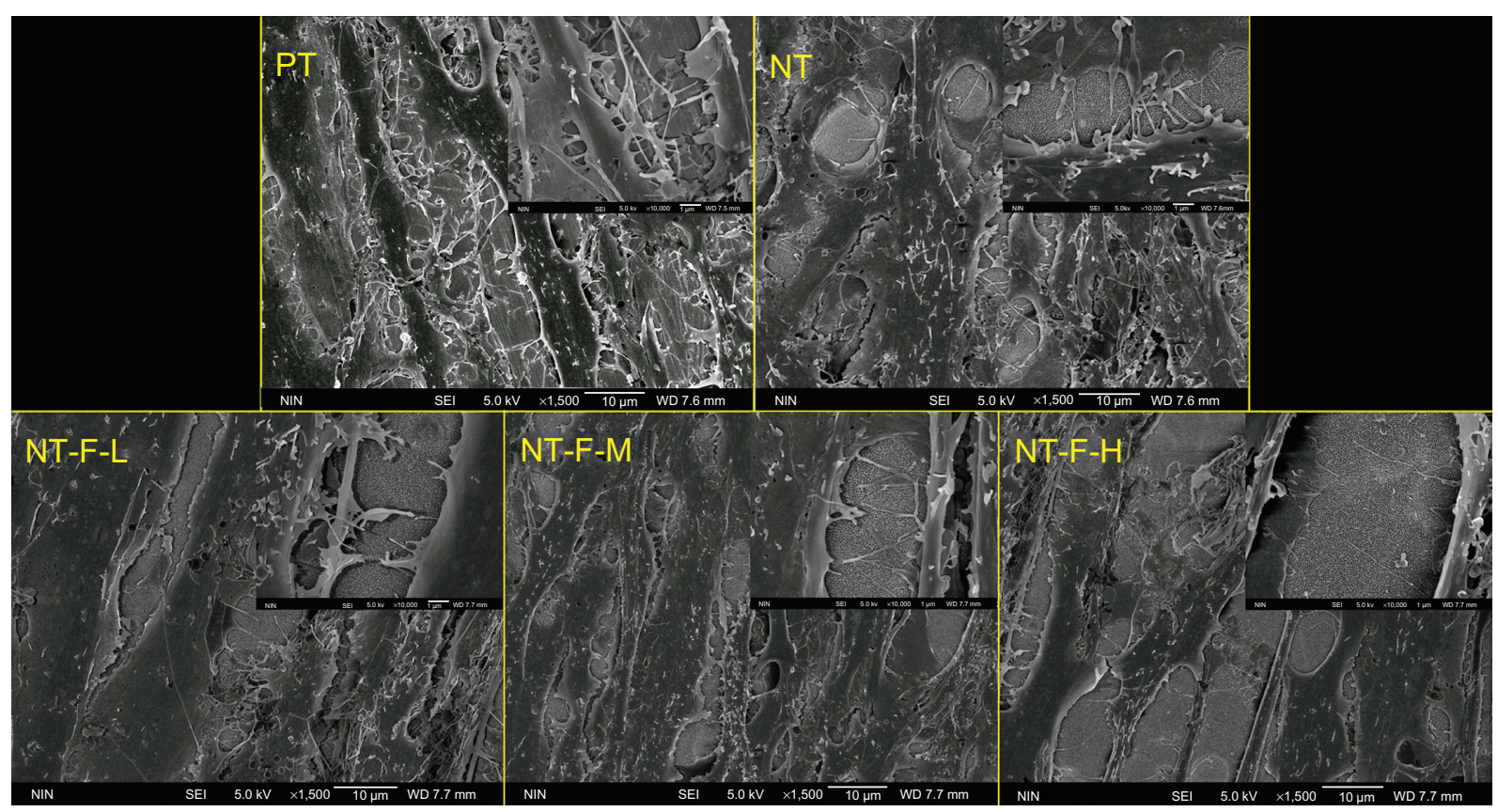

Figure 7 Morphology of HGFs: (A) PT, (B) NT, (C) NT-F-L, (D) NT-F-M, and (E) NT-F-H lacking sufficient prominences/pseudopods and not fusing together. Abbreviations: HGF, human gingival fibroblast; NT, nanotube; PT, polished titanium. 
A
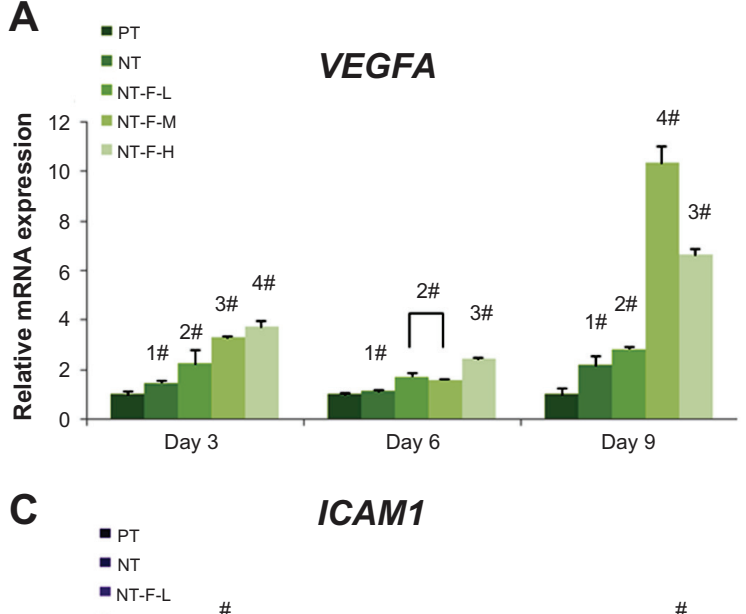

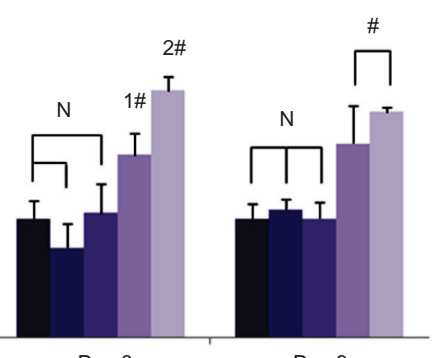

Day 3

Day 6

Day 9

B

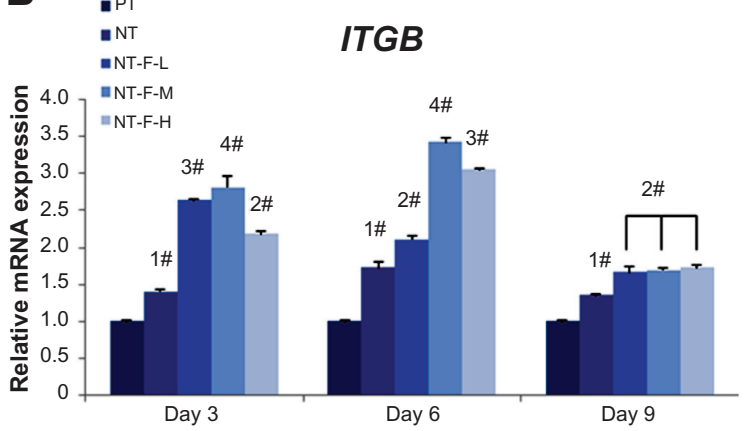

D

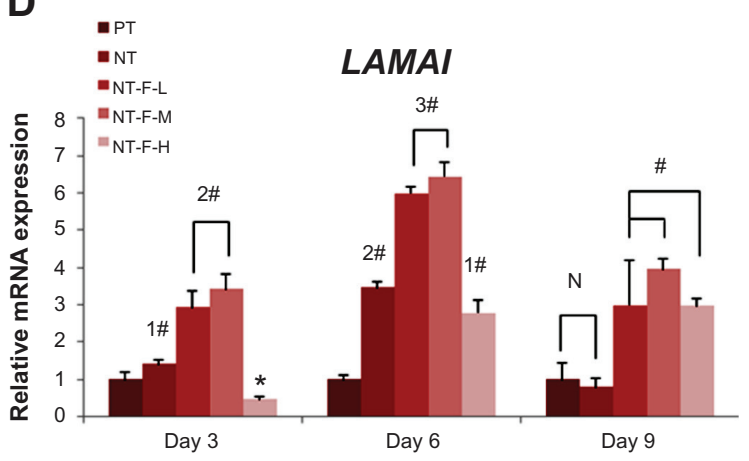

Figure 8 Extracellular matrix-related gene expressions by HGFs cultured on four different titanium surfaces at Days 3, 6, and 9: (A) VEGFA, (B) ITGB, (C) ICAMI, and (D) LAMAI. Inverse concentration-dependent effects of NT-F-H were observed at Day 3 on (C) and (D).

Notes: \#Upregulated compared with PT $(P<0.0 \mathrm{I})$, *downregulated $(P<0.0 \mathrm{I})$, significant difference exists between $I^{*}, 2^{*}, I^{\#}$, and $2^{*}(P<0.0 \mathrm{I})$.

Abbreviations: HGF, human gingival fibroblast; ICAMI, intercellular adhesion molecule I; ITGB, $\beta$-integrin; LAMAI, laminin-I; NT, nanotube; PT, polished titanium; VEGFA, vascular endothelial growth factor $\mathrm{A}$.

cell-substrate contact areas. The hollow structure of the $\mathrm{TiO}_{2}$ NT array may also inhibit the formation of focal adhesion. Integrin clustering and focal adhesion reinforcement are not influenced by the nanoscale pits with a diameter of $<70 \mathrm{~nm}$ irrespective of pit depth. However, increasing the size of the central lumen to $>70 \mathrm{~nm}$ in these vertically aligned NTs significantly reduces cellular adhesion. ${ }^{15,40}$ In this study, the attachment of HGFs is better on NT-F-L and NT-F-M than on NT, probably due to FGF2 immobilization. This offers functional regions to accelerate cell attachment and increases the contact area between the cells and substrate. The main reason for the suppressed HGF attachment on NT-F-H may be the direct contact with the clumps of FGF2 on NT-F-H with over FGF2 immobilization. According to FE-SEM results and FGF2 elution kinetics, when the samples are immersed in the culture medium, the clumps of FGF2 dissolve rapidly, leaving the HGFs with a relatively unstable environment and making HGFs hard to attach.

Inverse concentration-dependent effect has been observed in the proliferation of HGFs on NT-F-H, which was much less than that on PT on Days 1 and 3, but gradually increased by Days 6 and 9. On the contrary, both NT-F-L and NT-F-M demonstrated excellent performance in terms of proliferation at all time points. Our results illustrate the enhanced behavior of fibroblasts in a medium with the appropriate concentration of eluted FGF2. Referring to the results in Figure 9 and

Table 4 Summary of extracellular matrix-related gene expressions on Days 3, 6, and 9

\begin{tabular}{|c|c|c|c|c|c|c|c|c|c|c|c|c|}
\hline & \multicolumn{3}{|c|}{ VEGFA } & \multicolumn{3}{|c|}{ ITGB } & \multicolumn{3}{|c|}{ ICAMI } & \multicolumn{3}{|c|}{ LAMAI } \\
\hline & D3 & D6 & D9 & D3 & D6 & D9 & D3 & D6 & D9 & D3 & D6 & D9 \\
\hline NT & + & + & + & + & + & + & I & I & I & + & +2 & I \\
\hline NT-F-L & +2 & +2 & +2 & +3 & +2 & +2 & I & I & 1 & +2 & +3 & + \\
\hline NT-F-M & +3 & +2 & +4 & +4 & +4 & +2 & + & + & + & +2 & +3 & + \\
\hline NT-F-H & +4 & +3 & +3 & +2 & +3 & +2 & - & +2 & + & - & + & + \\
\hline
\end{tabular}

Notes: +, Upregulated compared with PT $(P<0.01)$; -, downregulated $(P<0.01)$; I, no significant difference compared with PT.

Abbreviations: ICAMI, intercellular adhesion molecule I; ITGB, $\beta$-integrin; LAMAI, laminin-I; NT, nanotube; PT, polished titanium; VEGFA, vascular endothelial growth factor A. 


\section{Activity of dissolvable FGF2}

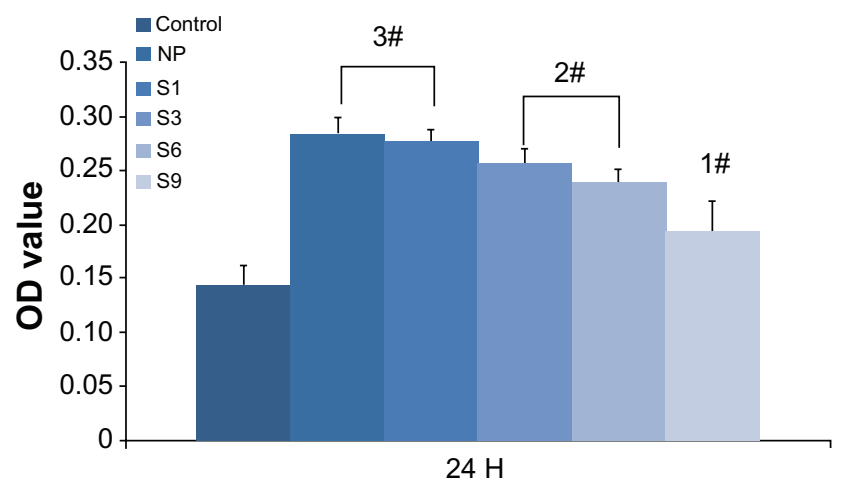

Figure 9 Activity changes of dissolvable FGF2 (10 ng/mL): control (FGF2-free); newly prepared Dulbecco's modified Eagle's medium; and SI, S3, S6, and S9 (FGF2 in Dulbecco's modified Eagle's medium stored for I day, 3 days, 6 days, or 9 days, respectively). The activity of FGF2 reduced gradually in culture medium with time and dropped to less than $50 \%$ after 9 days (S9) compared with NP.

Note: \#Higher than PT $(P<0.01)$, significant difference exists between I\#, $2^{\#}$, and $3^{\#}$ $(P<0.01)$.

Abbreviations: FGF2, fibroblast growth factor 2; NT, nanotube; OD, optical density; PT, polished titanium.

Table 3, the activity and concentrations of eluted FGF2 from NT-F-L, -M, and -H are all suitable for cell proliferation within 3 days $(10-100 \mathrm{ng} / \mathrm{mL}),{ }^{22}$ whereas NT-F-H shows extremely low proliferation. An unstable microenvironment is probably the main reason for this suppressive effect. On the NT-F-H surface, FGF2 dissolves within the first day and impedes the attachment of HGFs, therefore delaying their proliferation when compared with those on NT-F-L and NT-F-M. In all organ systems, the normal mammalian response to injury occurs in three overlapping but distinctive stages: (1) inflammation, (2) new tissue formation, and (3) remodeling. Stage 1 lasts for about 2 days after injury, whereas Stage 2 occurs $2-10$ days after injury and is characterized by cellular proliferation. ${ }^{41}$ Therefore, early proliferation of HGFs after implantation is crucial to healthy soft tissue sealing, and
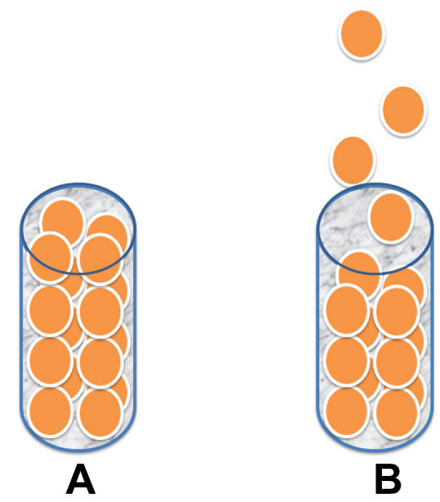

FGF2

\section{Nanotube}

Figure 10 Pattern of nanotube-based FGF2 control release system: (A) initial stage, (B) in culture medium, FGF2 is gradually released from the nanotubes. Abbreviation: FGF2, fibroblast growth factor 2 . concentration-related impeded proliferation should be avoided.

In the morphogenesis of virtually all tissues, the ECM is essential and forms a structural framework possessing signal-transducing receptors that interact with cells. VEGFA enhances blood vessel growth and permeability and is a powerful mitogen for endothelial cells, fulfilling an important role in angiogenesis. ${ }^{42,43}$ Hence, an FGF2-immobilized $\mathrm{TiO}_{2}$ nanotubular surface may promote vascularization and further accelerate soft tissue regeneration around dental implants. In this work, the VEGFA expressions of NT, NT-F-L, -M, and $-\mathrm{H}$ are all upregulated, and NT-F-H shows the highest expression on Days 3 and 6. Overexpression of VEGFA may produce tissue inflammation or edema, thereby delaying tissue regeneration.

Integrins constitute the primary family of cell-surface receptors that mediate attachment to the ECM and substrates ${ }^{44}$ and play a key role in early signal transduction..$^{45}$ In the integrin family, $\beta$-integrin is important in cellular binding on coated or textured Ti implants. ${ }^{46}$ The total ITGB expression levels are concentration-dependent and increased by FGF $2{ }^{47}$ In this study, NT-stimulated ITGB is overexpressed at all time points, because the nanotubular surface hinders cellular attachment in the early stage but improves ITGB expression due to reverse compensation. NT-F-L, -M, and - $\mathrm{H}$ significantly enhance $I T G B$ expression at all time intervals, and NT-F-M shows the highest gene expression among them on Days 3 and 6. However, this trend is not observed at Day 9. The probable reason may be that ITGB is richly expressed during the early stages. After cell-material integration has occurred, the expression of $I T G B$ is less sensitive to the various concentrations of FGF2. Unlike VEGFA expression, excessive FGF2 does not give rise to a reverse effect but cannot fully exert its bioactivity. The $\mathrm{TiO}_{2}$ nanotubular surface is probably the main factor regulating ITGB expression after Day 9.

ICAM1, which is a widely expressed cell adhesion molecule ${ }^{48-50}$ and belongs to the immunoglobulin super family, plays an important physiological role in routing polymorphonuclear neutrophils to the gingival sulcus efficiently and initiating a host response toward the implant. The expression of endothelial cell adhesion molecules (CAMs) for leukocytes, P-selectin, E-selectin, and ICAM1 is significantly upregulated in inflamed tissues by FGF2. ${ }^{51}$ Our results reveal that the $\mathrm{TiO}_{2}$ nanotubular surface does not affect ICAMI expression, and even the NT-F-L's efficacy is nil. It is only when the concentration of FGF2 reaches a certain threshold that the effect is observed, 
thereby impairing (NT-F-H, Figure 8C, Day 3) or enhancing (NT-F-M Figure 8C, Days 3, 6, and 9; NT-F-H, Figure 8C, Days 6 and 9) ICAM1 expression. This effect may result in the increase of intercellular adhesion in the early stage as well as recruitment of polymorphonuclear neutrophils to produce anti-infective activity in the long term, ${ }^{50}$ thereby improving the microecological environment around the dental implant.

Laminins are CAMs found predominantly in basement membranes ${ }^{52}$ and may help to form a base for cell-substrate adhesion and improve the interface between cells (even epithelium) and dental implants. The mRNA levels of laminin in periodontal ligament cells are specifically upregulated by FGF2 stimulation. ${ }^{36}$ In this study, both the $\mathrm{TiO}_{2}$ nanotubular surface and FGF2 exhibit stimulated the LAMA1 expression. The inverse concentration-dependent effect was significantly observed on NT-F-H on Days 3 and 6 but diminished on Day 9.

From the perspective of cell adhesion, proliferation, and ECM-related gene expression, our results reveal that the functions of FGF2 immobilized on $\mathrm{TiO}_{2}$ nanotubular surface are definitely bidirectional as well as concentration- and time-dependent. The FGF2 solution with a concentration of $500 \mathrm{ng} / \mathrm{mL}$ is optimal for repeated lyophilization in spite of some loss of bioactivity with time. The $\mathrm{TiO}_{2}$ nanotubular surface might be ideal because its microstructure facilitates FGF2 immobilization, storage, and controlled release within 9 days. However, overimmobilization of FGF2 could lead to unwanted impairment of tissue healing and must therefore be avoided. Although the NT-based drug control release system needs further research for optimization, this FGF2/ $\mathrm{TiO}_{2}$ nanotubular surface (NT-F-M) modification may lead to excellent gingival tissue-implant integration in vivo and has promising applications in dentistry and other biomedical devices.

\section{Acknowledgments}

This work was supported financially by the National Natural Science Fund No 81070862 and 31170915 , City University of Hong Kong Applied Research Grants (ARG) No 9667038 , and Hong Kong Research Grants Council (RGC) General Research Funds (GRF) No CityU 112510.

\section{Ethical approval}

The Medical Ethics Committee of the School of Stomatology of the Fourth Military Medical University approved this study. The study adhered to the tenets of the Declaration of Helsinki. All three patients gave written informed consent.

\section{Disclosure}

The authors report no conflict of interest relevant to this research.

\section{References}

1. Adell R, Eriksson B, Lekholm U, Branemark PI, Jemt T. Long-term follow-up study of osseointegrated implants in the treatment of totally edentulous jaws. Int J Oral Maxillofac Implants. 1990;5(4): 347-359.

2. Arvidson K, Bystedt H, Frykholm A, von Konow L, Lothigius E. Five-year prospective follow-up report of the Astra Tech Dental Implant System in the treatment of edentulous mandibles. Clin Oral Implants Res. 1998;9(4):225-234.

3. Olsson M, Gunne J, Astrand P, Borg K. Bridges supported by free-standing implants versus bridges supported by tooth and implant. A five-year prospective study. Clin Oral Implants Res. 1995;6(2): $114-121$.

4. Abrahamsson I, Berglundh T, Lindhe J. The mucosal barrier following abutment dis/reconnection. An experimental study in dogs. J Clin Periodontol. 1997;24(8):568-572.

5. Lindhe J, Berglundh T. The interface between the mucosa and the implant. Periodontology 2000. 1998;17(1):47-54.

6. Schwarz F, Ferrari D, Herten M, et al. Effects of surface hydrophilicity and microtopography on early stages of soft and hard tissue integration at non-submerged titanium implants: an immunohistochemical study in dogs. J Clin Periodontol. 2007;78(11):2171-2184.

7. Abrahamsson I, Berglundh T, Lindhe J. Soft tissue response to plaque formation at different implant systems. A comparative study in the dog. Clin Oral Implants Res. 1998;9(2):73-79.

8. Abrahamsson I, Cardaropoli G. Peri-implant hard and soft tissue integration to dental implants made of titanium and gold. Clin Oral Implants Res. 2007;18(3):269-274.

9. Faveri M, Goncalves LF, Feres M, et al. Prevalence and microbiological diversity of Archaea in peri-implantitis subjects by 16 S ribosomal RNA clonal analysis. J Periodontal Res. 2011;46(3):338-344.

10. Shibli JA, Melo L, Ferrari DS, Figueiredo LC, Faveri M, Feres M. Composition of supra- and subgingival biofilm of subjects with healthy and diseased implants. Clin Oral Implants Res. 2008;19(10): 975-982.

11. Brunette D. Effects of surface topography of implant materials on cell behavior in vitro and in vivo. Nanofabrication and Biosystems: Integrating Materials Science, Engineering, and Biology. 1996: 335-355.

12. Zhao L, Mei S, Wang W, Chu PK, Wu Z, Zhang Y. The role of sterilization in the cytocompatibility of titania nanotubes. Biomaterials. 2010;31(8):2055-2063.

13. Gong D, Grimes C, Varghese OK, et al. Titanium oxide nanotube arrays prepared by anodic oxidation. J Mater Res. 2001;16(12): 3331-3334.

14. Balasundaram G, Yao C, Webster TJ. TiO2 nanotubes functionalized with regions of bone morphogenetic protein-2 increases osteoblast adhesion. J Biomed Mater Res A. 2008;84(2):447-453.

15. Park J, Bauer S, von der Mark K, Schmuki P. Nanosize and vitality: TiO2 nanotube diameter directs cell fate. Nano Lett. 2007;7(6):1686-1691.

16. Brammer KS, Oh S, Cobb CJ, Bjursten LM, Heyde H, Jin S. Improved bone-forming functionality on diameter-controlled $\mathrm{TiO} 2$ nanotube surface. Acta Biomaterialia. 2009;5(8):3215-3223.

17. von Wilmowsky C, Bauer S, Lutz R, et al. In vivo evaluation of anodic TiO2 nanotubes: an experimental study in the pig. J Biomed Mater Res B Appl Biomater. 2009;89(1):165-171.

18. Demetrescu I, Pirvu C, Mitran V. Effect of nano-topographical features of $\mathrm{Ti} / \mathrm{TiO} 2$ electrode surface on cell response and electrochemical stability in artificial saliva. Bioelectrochemistry. 2010;79(1):122-129.

19. Ornitz DM, Itoh N. Fibroblast growth factors. Genome Biol. 2001;2(3): 3005 . 
20. Gerritsen ME, Soriano R, Yang S, et al. Branching out: a molecular fingerprint of endothelial differentiation into tube-like structures generated by affymetrix oligonucleotide arrays. Microcirculation. 2003;10(1):63-81.

21. Palmon A, Roos H, Edel J, et al. Inverse dose- and time-dependent effect of basic fibroblast growth factor on the gene expression of collagen type I and matrix metalloproteinase- 1 by periodontal ligament cells in culture. J Periodontol. 2000;71(6):974-980.

22. Takayama S, Murakami S, Miki Y, et al. Effects of basic fibroblast growth factor on human periodontal ligament cells. J Periodontal Res. 1997;32(8):667-675.

23. Pitaru S, Kotev-Emeth S, Noff D, Kaffuler S, Savion N. Effect of basic fibroblast growth factor on the growth and differentiation of adult stromal bone marrow cells: enhanced development of mineralized bone-like tissue in culture. J Bone Miner Res. 1993;8(8):919-929.

24. Kokubu E, Yoshinari M, Matsuzaka K, Inoue T. Behavior of rat periodontal ligament cells on fibroblast growth factor-2-immobilized titanium surfaces treated by plasma modification. J Biomed Mater Res A. 2009;91(1):69-75.

25. Peng L, Mendelsohn AD, LaTempa TJ, Yoriya S, Grimes CA, Desai TA. Long-term small molecule and protein elution from $\mathrm{TiO} 2$ nanotubes. Nano Lett. 2009;9(5):1932-1936.

26. Hankemeier S, Keus M, Zeichen J, et al. Modulation of proliferation and differentiation of human bone marrow stromal cells by fibroblast growth factor 2: potential implications for tissue engineering of tendons and ligaments. Tissue Eng. 2005;11(1-2):41-49.

27. Mustafa K, Silva Lopez B, Hultenby K, Wennerberg A, Arvidson K. Attachment and proliferation of human oral fibroblasts to titanium surfaces blasted with $\mathrm{TiO} 2$ particles. A scanning electron microscopic and histomorphometric analysis. Clin Oral Implants Res. 1998;9(3):195-207.

28. Yoshinari M, Matsuzaka K, Inoue T, Oda Y, Shimono M. Effects of multigrooved surfaces on fibroblast behavior. J Biomed Mater Res A. 2003;65(3):359-368.

29. Kim S-Y, Oh N, Lee M-H, Kim S-E, Leesungbok R, Lee S-W. Surface microgrooves and acid etching on titanium substrata alter various cell behaviors of cultured human gingival fibroblasts. Clin Oral Implants Res. 2009;20(3):262-272.

30. Gelover S, Gomez LA, Reyes K, Teresa Leal M. A practical demonstration of water disinfection using $\mathrm{TiO} 2$ films and sunlight. Water Research. 2006;40(17):3274-3280.

31. Livak KJ, Schmittgen TD. Analysis of relative gene expression data using real-time quantitative PCR and the 2(-Delta Delta C(T)) method. Methods. 2001;25(4):402-408.

32. Schultz GS, Wysocki A. Interactions between extracellular matrix and growth factors in wound healing. Wound Repair Regen. 2009;17(2): $153-162$.

33. Sul YT, Johansson CB, Petronis S, et al. Characteristics of the surface oxides on turned and electrochemically oxidized pure titanium implants up to dielectric breakdown: the oxide thickness, micropore configurations, surface roughness, crystal structure and chemical composition. Biomaterials. 2002;23(2):491-501.

34. Shibli JA, Grassi S, de Figueiredo LC, et al. Influence of implant surface topography on early osseointegration: a histological study in human jaws. J Biomed Mater Res B Appl Biomater. 2007;80(2):377-385.

35. Zhao L, Mei S, Chu PK, Zhang Y, Wu Z. The influence of hierarchical hybrid micro/nano-textured titanium surface with titania nanotubes on osteoblast functions. Biomaterials. 2010;31(19):5072-5082.

International Journal of Nanomedicine

\section{Publish your work in this journal}

The International Journal of Nanomedicine is an international, peerreviewed journal focusing on the application of nanotechnology in diagnostics, therapeutics, and drug delivery systems throughout the biomedical field. This journal is indexed on PubMed Central, MedLine, CAS, SciSearch $\AA$, Current Contents ${ }^{\circledR} /$ Clinical Medicine,
36. Murakami S, Takayama S, Ikezawa K, et al. Regeneration of periodontal tissues by basic fibroblast growth factor. J Periodontal Res. 1999;34(7): 425-430.

37. Nakahara T, Nakamura T, Kobayashi E, et al. Novel approach to regeneration of periodontal tissues based on in situ tissue engineering: effects of controlled release of basic fibroblast growth factor from a sandwich membrane. Tissue Eng. 2003;9(1):153-162.

38. Akman AC, Tigli RS, Gumusderelioglu M, Nohutcu RM. bFGF-loaded HA-chitosan: a promising scaffold for periodontal tissue engineering. J Biomed Mater Res A. 2010;92(3):953-962.

39. Filion RJ, Popel AS. Intracoronary administration of FGF-2: a computational model of myocardial deposition and retention. Am J Physiol Heart Circ Physio. 2005;288(1):H263-H279.

40. Biggs MJ, Richards RG, Dalby MJ. Nanotopographical modification: a regulator of cellular function through focal adhesions. Nanomedicine. 2010;6(5):619-633.

41. Gurtner GC, Werner S, Barrandon Y, Longaker MT. Wound repair and regeneration. Nature 2008;453(7193):314-321.

42. Johnson RB, Serio FG, Dai X. Vascular endothelial growth factors and progression of periodontal diseases. J Periodontol. 1999;70(8): $848-852$.

43. Connolly DT. Vascular permeability factor: a unique regulator of blood vessel function. J Cell Biochem. 1991;47(3):219-223.

44. Diamond MS, Springer TA. The dynamic regulation of integrin adhesiveness. Curr Biol. 1994;4(6):506-517.

45. Clark EA, Brugge JS. Integrins and signal transduction pathways: the road taken. Science. 1995;268(5208):233-239.

46. Kramer PR, Janikkeith A, Cai Z, Ma S, Watanabe I. Integrin mediated attachment of periodontal ligament to titanium surfaces. Dent Mater. 2009;25(7):877-883.

47. Suzuki Y, Yanagisawa M, Yagi H, Nakatani Y, Yu RK. Involvement of beta1-integrin up-regulation in basic fibroblast growth factor- and epidermal growth factor-induced proliferation of mouse neuroepithelial cells. J Biol Chem. 2010;285(24):18443-18451.

48. Crawford JM, Hopp B. Junctional epithelium expresses the intercellular adhesion molecule ICAM-1. J Periodontal Res. 1990;25(4): 254-256.

49. Norris P, Poston RN, Thomas DS, Thornhill M, Hawk J, Haskard DO. The expression of endothelial leukocyte adhesion molecule-1 (ELAM-1), intercellular adhesion molecule-1 (ICAM-1), and vascular cell adhesion molecule-1 (VCAM-1) in experimental cutaneous inflammation: a comparison of ultraviolet B erythema and delayed hypersensitivity. J Invest Dermatol. 1991;96(5):763-770.

50. Moughal NA, Adonogianaki E, Thornhill MH, Kinane DF. Endothelial cell leukocyte adhesion molecule-1 (ELAM-1) and intercellular adhesion molecule-1 (ICAM-1) expression in gingival tissue during health and experimentally-induced gingivitis. J Periodontal Res. 1992;27(6):623-630.

51. Zittermann SI, Issekutz AC. Basic fibroblast growth factor (bFGF, FGF-2) potentiates leukocyte recruitment to inflammation by enhancing endothelial adhesion molecule expression. Am J Pathol. 2006;168(3): 835-846.

52. Durbeej M. Laminins. Cell Tissue Res. 2010;339(1):259-268.

Journal Citation Reports/Science Edition, EMBase, Scopus and the Elsevier Bibliographic databases. The manuscript management system is completely online and includes a very quick and fair peer-review system, which is all easy to use. Visit http://www.dovepress.com/ testimonials.php to read real quotes from published authors. 